\title{
Impacts of Market Gardening Practices on Environmental Resources: The Case of Irrigable Lands in Bonkoukou (Imanan Rural Municipality, SW Niger Republic)
}

\author{
Karimou Dia Hantchi ${ }^{*}$, Salamatou Abdourahamane Illiassou ${ }^{2}$, Adamou Didier Tidjani ${ }^{3}$ \\ Rachid Boubacar Oumarou ${ }^{4}$, Zibo Garba ${ }^{4}$ \\ ${ }^{1}$ Department of Geology, Faculty of Science and Techniques, Dan Dicko Dankoulodo University, Maradi, Niger \\ ${ }^{2}$ Department of Animal Production, Faculty of Agronomic Science, University of Diffa, Diffa, Niger \\ ${ }^{3}$ Department of Soil Science, Faculty of Agronomy, Abdou Moumouni University, Niamey, Niger \\ ${ }^{4}$ Department of Digitization of Environmental Science, Faculty of Science and Techniques, University of Dosso, Dosso, Niger \\ Email: *diah.uddkm@gmail.com
}

How to cite this paper: Hantchi, K.D., Illiassou, S.A., Tidjani, A.D., Oumarou, R.B. and Garba, Z. (2022) Impacts of Market Gardening Practices on Environmental Resources: The Case of Irrigable Lands in Bonkoukou (Imanan Rural Municipality, SW Niger Republic). Natural Resources, 13, 16-37. https://doi.org/10.4236/nr.2022.131002

Received: December 17, 2021

Accepted: January 25, 2022

Published: January 28, 2022

Copyright $\odot 2022$ by author(s) and Scientific Research Publishing Inc. This work is licensed under the Creative Commons Attribution International License (CC BY 4.0).

http://creativecommons.org/licenses/by/4.0/

\begin{abstract}
Due to increasingly extreme climatic conditions in the Sahel, irrigated crops are emerging as imperative innovations for agricultural transformation and resilience. This study is designed to assess the impact of market gardening on soil, water and plant cover in the western Niger Republic. Semi-structured survey data were collected from 78 site operators in the Imanan rural municipality (Filingué, Tillabéry). In addition to the survey, a photographic collection illustrated certain observable facts in the field. The survey shows that the wooden enclosures (70.65\% of respondents) around the fields are renewed every year. The impacts are then substantial: deforestation of plateaus, clearing of valleys for new extensions, loss of wildlife habitat, changes in the water flow regime resulting from a geomorphological change in the commune. Itou, the preparation of the planks consumes a lot of water. Thus, the new sinking of water points and the load pressure increase the drawdowns of wells and boreholes in the sites (75.46\% of respondents). The frequent spills of waste oil on the sites, as well as the numerous potato storage pits, are among the factors and vectors most likely to contaminate the soils and aquifers of the study area. Market gardening destabilizes the soils and induces regressive erosion as well as area runoff of rainwater on all sites and on the slopes. On the other hand, slash-and-burn practices, drying of branches intended for fences, as well as rain-fed cowpea crops, promote improved physical properties and soil fertilization. To reduce the risks of disintegration and especially of silting up of sites, the study suggests a policy of live hedges and wire fences so that
\end{abstract}


common spaces can be imposed on operators.

\section{Keywords}

Market Gardening, Impacts, Environmental Resources, Degradation, Imanan, Niger

\section{Introduction}

In Niger, agricultural activities represent the main socio-economic activity, practiced by more than $80 \%$ of the population [1]. It spans in the southern strip of the country, between the $300 \mathrm{~mm}$ and $800 \mathrm{~mm}$ isohyets [2]. Several challenges hamper these agricultural activities. At the height of the spatiotemporal variability of precipitation, only $12 \%$ of the surface of the national territory is favorable to rainfed crops production [3]. Nevertheless, the desertification and, above all, recurrent droughts greatly increase soil infertility and hence hamper these activities [1] [3]. As an adaptation, nigerien production system remains extensive, and is practiced on increasingly poor soils [4]. In addition to these threats, there is the threat of climate change and rampant urbanization due to the increase in rural exodus combined with population growth [5]. The extensive character of this agriculture in line with all other climatic and anthropic challenges continuously increases the vulnerability of the agricultural systems in Niger.

To alleviate these impacts and increase the resilience of these farmer communities, market gardening seems quite suitable and constitutes an inescapable logic in Niger. Indeed, irrigation is considered the best way to increase agricultural production and reduce its vulnerability to climate variability [6]. Consequently, various projects on wetlands such as the valleys (e.g. Aïr Sahara and Azaouagh, Goulbi-Tarka, Dallols, and Ader-Doutchi-Tahoua Magia) have been maintained and extended to refine a groundwater mobilization policy. From this achievement, the Aïr Sahara is recognized today through the production of potato, Galmi (Ader Tahoua) through the production of onion and Djiratawa (Goulbi Maradi) for Anice and Moringa, Imanan (Dallol Tillabéry, western Niger) is developing the potato sector and is in second place nationally [7].

These irrigated crops greatly improve the livelihood of the population. For instance, according to [8], potato production has greatly contributed to improving the living conditions of the populations of Imanan and has made it possible to obviate certain socio-economic disparities. This fits perfectly with the policy of the Sustainable Development Goal (SDG) by 2030 [9]. However, the references to the management of the environmental impacts linked to these market gardening activities are very laconic, both in terms of the health of farmers and in terms of development pressures on the environment [8]. This situation illustrates the vulnerability of the sector and the impact of poor implementation of strategies [9]. Hence, the objective of this study is to identify the variables and constraints of vegetable production from farmers' perceptions of the farming 
system and to demonstrate their positive or negative impacts on water (underground and surface), soils and vegetation cover, as major components of the physical environment.

\section{Material and Methods}

\subsection{Area of Study}

This study was carried out in the Bonkoukou potential irrigable lands of the South West Niger Republic. Bonkoukou (14 ${ }^{\circ} 00^{\prime} 37^{\prime \prime} \mathrm{N}$ and $\left.3^{\circ} 12^{\prime} 42^{\prime \prime} \mathrm{E}\right)$ is located about $145 \mathrm{~km}$ north-east of Niamey, the capital of Niger (Figure 1). It is the county town of the rural municipality of Imanan, in the department of Filingué (Tillabery Region; Figure 1). The Imanan Commune covers a total area of $506.06 \mathrm{~km}^{2}$ [10]. It counts 46,734 people (2016) living in 53 administrative villages and seven administrative districts [5]. Imanan is located in the South Western Sahel compartment, with a rainfall index ranging between 300 and 600 $\mathrm{mm}$ [6] [9]. The highest temperatures are recorded in April and May $\left(45^{\circ} \mathrm{C}\right)$ and the lowest in February $\left(18^{\circ} \mathrm{C}\right)[11]$.

The landscape of Imanan is marked by two dominant reliefs: the fossil valley and the plateaus [12]. Within these two sets, a mosaic of agroecological facies emerges which present quite contrasting characteristics and sometimes profound disparities in the suitability of use of the environments [11]. More characteristic is the centering of the rural commune on a section of the valley of Bosso

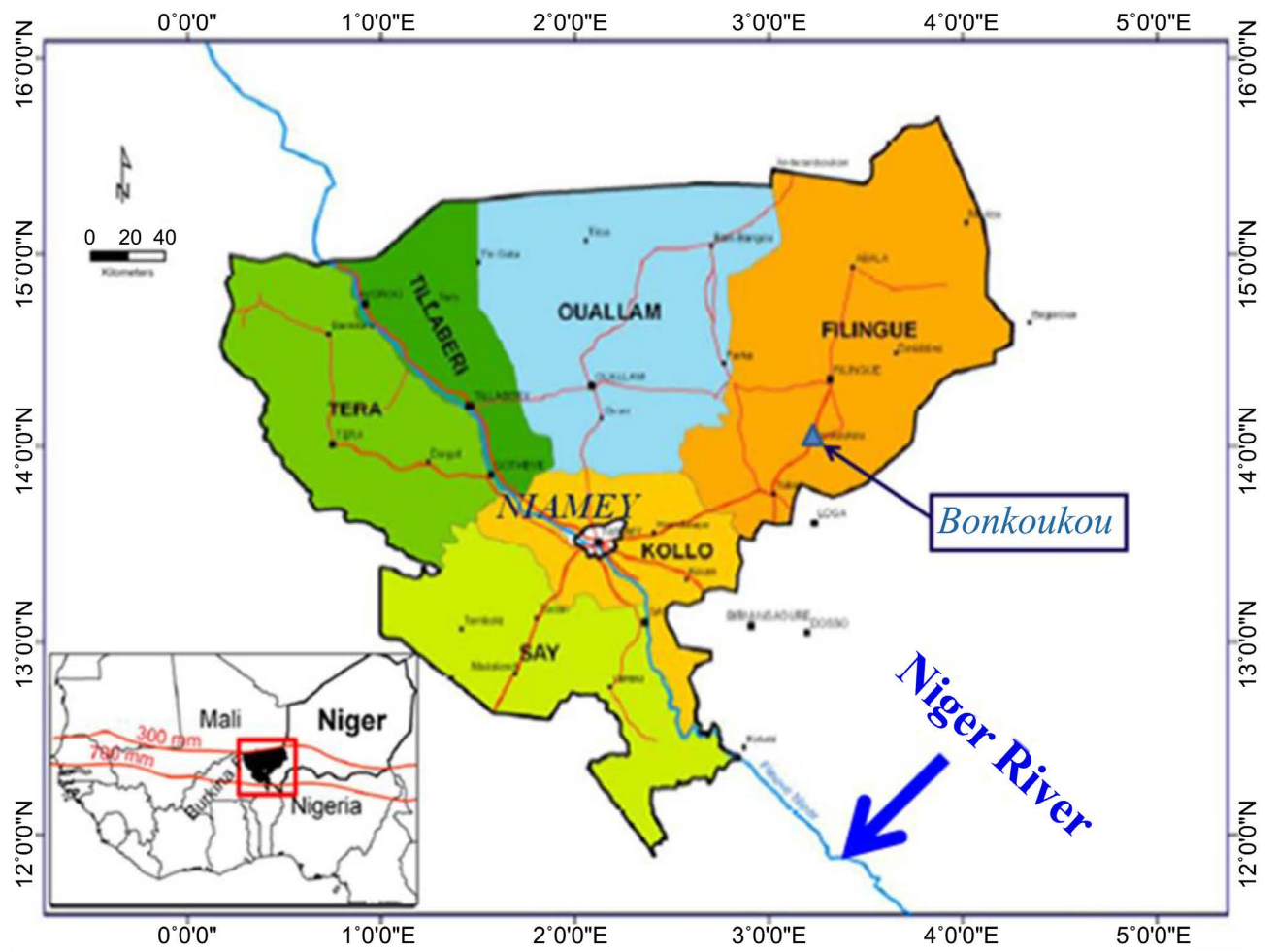

(a)

(b)

Figure 1. Maps showing (A) isohyets 1951-1989 of the SW of Niger and location of Tillabery Region [6], and (B) localization of Bonkoukou within Filingué department (Tillabery Region). 
Dallol which narrows on five kilometers wide before widening again towards the south [10]. The Bosso Dallol is an ancient dried-up stream that descends from the southern foothills of the Aïr massif [12]. Thus, with its main tributary (the Azagaret), the Dallol Bosso extends to the south the hydrographic network of the Azawak up to the confluence of the Niger River [12] (Figure 1).

The bottom of the Dallol Bosso valley is covered with sand forming soft undulations between which there are sometimes lowlands with heavy alluvial soils rich in silt [11]. It is these alluvial lands that, during the rainy season (wintering), more or less extensive ponds are formed. The plains are carpeted with sandy loam soils. These are areas for rainfed crops and extensive breeding in the dry season. They are very exploited and in places present dune complexes and glacis. In fact, this concerns land not only in full saturation with the marked decrease in fallow which leads to a scarcity of possibilities for extension, but also and above all the effects of the phenomenon of degradation. The glacis is covered with ferruginous soils that are not very cultivated and not very fertile.

On either side of the valley, the plateaus form a double line of cliffs with a drop of 35 to 40 meters, respectively to the east and to the west. At the level of the cliffs and slopes, the plateaus reveal several layers of clayey sandstone colored in pink, yellow or purple. These clayey sandstones are surmounted by a ferralitic cuirass of 1.50 to $2.50 \mathrm{~m}$ which bears witness to the so-called "intermediate" erosion surface [12]. To the east, the same sandstone plateau is also covered with cuirass. Overall, the plateaus have been cut by a network of small silted valleys with a discontinuous succession of lowlands which, more clayey and one to two kilometers wide, end in the Dallol [10].

The free-table aquifers, sometimes confused with the "water table" of Continental terminal $3\left(\mathrm{Ct}^{3}\right)$, are contained in Quaternary fluvial alluvium and are some 20 to $30 \mathrm{~m}$ thick [13]. Thus, water levels are generally located at an average depth of $14 \mathrm{~m}$ from the ground [6] (Figure 2). Groundwater reserves are estimated at around 5.163 billion $\mathrm{m}^{3}$ [10]. The increase in ions of chemical elements (e.g. $\mathrm{Na}^{+}, \mathrm{K}^{+}$and $\mathrm{Cl}^{-}$) in the superficial zone is due to the evaporation and leaching of salts accumulated in the unsaturated zone during the dry season [14]. According to the [10] the geographical coverage rate for drinking water in the rural commune of Imanan was $71.04 \%$ in 2018 , while the theoretical access rate was $49.43 \%$ for a rate of breakdown is $12.68 \%$. The piezometric fluctuations of free water tables are caused by the relatively faster infiltration of surface water during the rainy season (June to September) [15]. The waters of these aquifers are soft and slightly mineralized, but are very sensitive to pollution and/or bacteriological factors. As surface water, the rural commune of Imanan has five permanent ponds and 23 semi-permanent ponds. The Eggrou area has the most semi-permanent ponds. These ponds are mainly used for watering animals, for making bricks and for construction. Today, it is around some of them that fish farming and market gardening are developing [10]. The vegetation of the rural municipality of Imanan consists mainly of wooded and shrub steppes which differ according to the units of land and the type of soil it occupies [14]. 


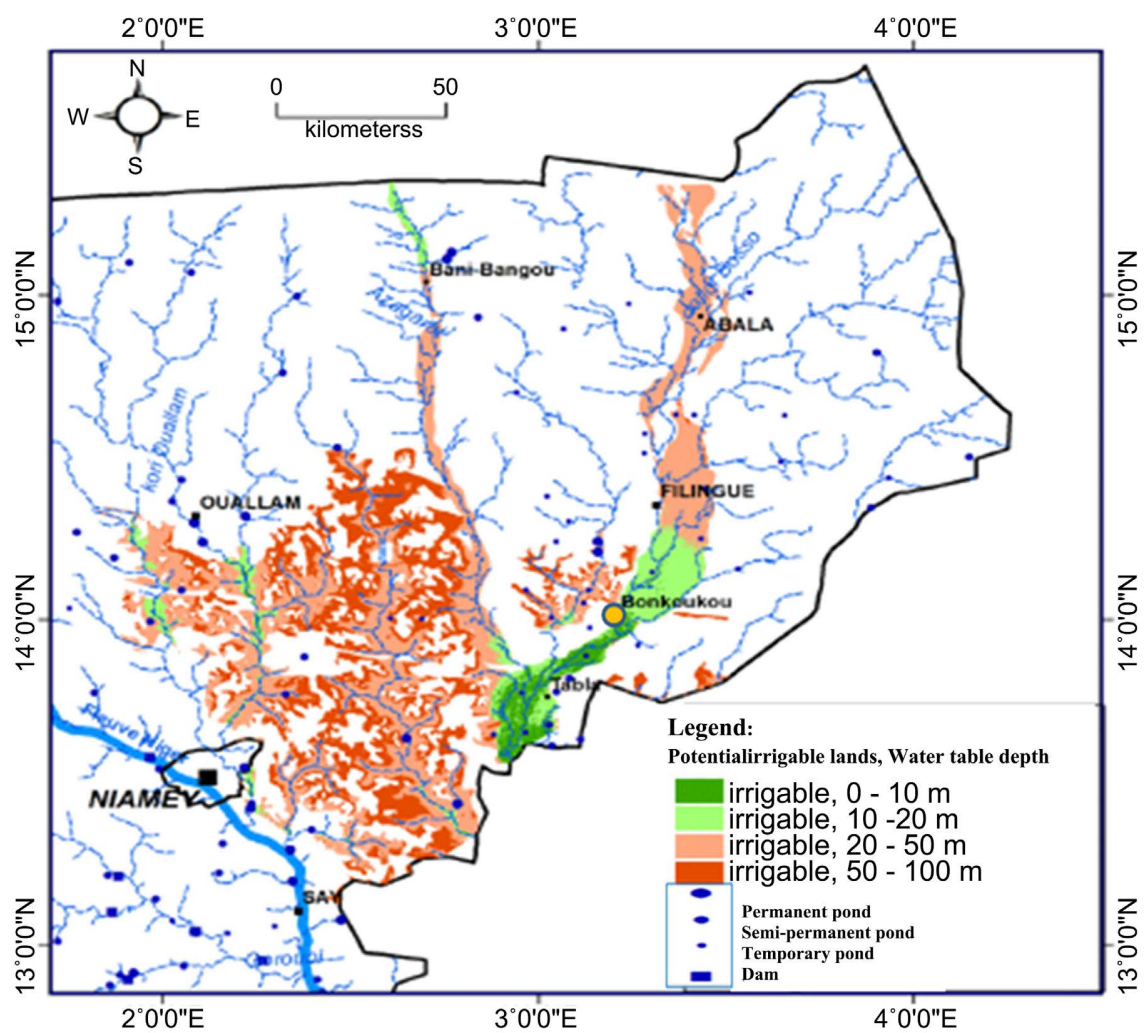

Figure 2. Potential irrigable lands as function of the water table depth [6].

\subsection{Methodologies}

The documentary approach is one of the three methods used to better frame the study area, along with exploratory studies and direct observation. Bibliographic research has been a privileged tool for gathering metadata on the data disseminated. It is in various documentations (journals, theses, technical reports and administrative documents) related to the subject that it is agreed to be interested, and more specifically in the Community Development Plan of Imanan (CDPI) [10].

The exploration phase took place from September $1^{\text {st }}$ to $9^{\text {th }}, 2020$. It consisted of visiting the various individual and collective market gardening sites in the rural commune of Imanan. Subsequently, several actors in the field were approached. These include, among others, the notables of Bonkoukou, the technical and administrative services, the heads of the market gardening group, the staff of FCMN Niyya. At this stage of exploration, the goal is to gather information about their activity and create comparative data. The profile of the vegetable production system is established by considering the sites visited and the value provided by the findings and observations of each of these components. At this level, sampling was carried out on five (5) collective sites (Balley Koira, Iguefane, Eggrou, Kochilan Tuareg and Femmes INRAN) of the 17 collective sites (i.e. $29.41 \%$ ), two (2) hamlets (Labongou and Inacli) and individual sites in Bonkoukou. The choice of these sites is based primarily on the number of producers that they abound, in addition to the proximity of the villages and hamlets of the 
operators to Bonkoukou, the capital of the commune. The idea of proximity is explained by the insecurity that undermines the area and the inability to get around on motorcycles. Thus, it was decided to write on a piece of paper the name of the villages and hamlets (selected for the draw) to draw randomly, one by one, the names of the villages and hamlets that were the object of this study. The results of the implementation of this diagnostic phase of the study areas are formalized through elaborate classes which made it possible to select ten (10) villages and four (4) hamlets to derive by discretization only the five (5) villages and two (2) hamlets mentioned above.

Direct observation consisted of a visit to the study area, to assess the reality of vegetable production at the selected sites. It took place from September $20^{\text {th }}$, 2020 to October $22^{\text {th }}, 2020$ in the study area, in addition to a one-week stay in Filingué. As a practical phase of the operational research in the field, it took place in three stages, namely an interview phase, a questionnaire administration phase and a phase of creation and documentation of qualitative data on the sites. The interview phase enabled discussions with departmental and municipal technical services, the Municipality of Imanan and the partners working in the area. Discussions focused on cultivation techniques, the contributions of technical services and community development partners in the preservation of environmental resources in the context of market gardening. The interview also concerned the different types of training that producers benefit from to ensure the sustainability of natural resources. The administration phase of the survey questionnaire, or the collection of data on the perception of operators vis-à-vis the practices and accompanying actions and policies in the context of the development of their activities. It involved measuring the socio-economic characteristics of market gardeners (e.g. lucrative activities), working conditions, crop protection methods, the impacts of agricultural activities on natural resources and the health status of the population. On the sites, the choice of market gardeners was also made randomly. In total (Table 1), 78 market gardeners were surveyed, including 56 men (or $71.79 \%$ of those surveyed) and 22 women (or $28.21 \%$ of those surveyed).

The creation and documentation of qualitative data on the sites include photographic shots of the modes of preparation and exploitation of the plots, the irrigation and crop protection systems, the surface conditions and all projections of the impacts of the activities, agriculture on the environment. This involves having, validating, weighing and comparing data relating to the perceptions of operators with those of the reality on the ground, in particular with regard to the various impacts on environmental components and the mitigation measures that are required.

The data collected in the field through the survey of market gardeners were entered and processed with Word and Excel software. The main elements taken into account in the processing of the data are the general characteristics of the producers surveyed (e.g. the level of education) and the factors of production. These include cultivation techniques (cropping systems, irrigation, etc.), the 
Table 1. Summary serving as a basis for the construction of a sample of operators surveyed on the sites.

\begin{tabular}{ccccc}
\hline Surveyed sites & $\begin{array}{c}\text { Number of } \\
\text { operators }\end{array}$ & $\begin{array}{c}\text { Operators } \\
\text { surveyed }\end{array}$ & Latitude & Longitude \\
\hline Balley Koira & 41 & 10 & $14^{\circ} 0^{\prime} 28^{\prime \prime} \mathrm{N}$ & $3^{\circ} 12^{\prime} 35^{\prime \prime} \mathrm{E}$ \\
Eggrou & 37 & 7 & - & - \\
Iguefane & 54 & 15 & - & - \\
INRAN Women & 36 & 13 & $14^{\circ} 0^{\prime} 20^{\prime \prime} \mathrm{N}$ & $3^{\circ} 13^{\prime} 10^{\prime \prime} \mathrm{E}$ \\
Kochilan Bella & 20 & 6 & $13^{\circ} 57^{\prime} 19^{\prime \prime} \mathrm{N}$ & $3^{\circ} 13^{\prime} 10^{\prime \prime} \mathrm{E}$ \\
Labangou & - & 4 & $14^{\circ} 04^{\prime} 51^{\prime \prime} \mathrm{N}$ & $3^{\circ} 13^{\prime} 56^{\prime \prime} \mathrm{E}$ \\
Inacli & - & 3 & $14^{\circ} 03^{\prime} 3^{\prime \prime} \mathrm{N}$ & $3^{\circ} 13^{\prime} 21^{\prime \prime} \mathrm{E}$ \\
Individual Owners & - & 20 & $13^{\circ} 51^{\prime} 43^{\prime \prime} \mathrm{N}$ & $3^{\circ} 19^{\prime} 53^{\prime \prime} \mathrm{E}$ \\
Total & 188 & 78 & & \\
\hline
\end{tabular}

directory of different types of inputs and their use, as well as the different types of fences. Finally, the impacts that these cultivation techniques and the inputs used are likely to have on environmental resources (water, soil and vegetation) were analyzed. Garmin brand GPS devices and an Android phone were used, respectively, to take geographic coordinates and photographs of the sites visited.

\section{Results}

\subsection{Main Determinants of Vegetable Production}

\subsubsection{Profiles of the Producers}

Market gardening is practiced by both men and women (Table 2). Note that people under 16 are not part of the sample. Among the 19 respondents who are between 16 and 30 years old, 15 are men against four women, for a total of $24.36 \%$ of the sample. In the $31-50$ age group, there are 28 men for seven women out of a workforce of 35 producers. Finally, for those aged 51 and over, 14 are men against ten women out of a total of 24 respondents $30.77 \%$ of the sample). It emerges from this survey that men are in the majority compared to women with $73.08 \%$ and $26.92 \%$ respectively. However, it is the respondents in the 31 - 50 age group who have an over-representation of producers (44.87\%).

Most of the producers surveyed are illiterate (47.43\%) and no farmer has higher education (Table 2). In addition, $29.95 \%$ of producers reached primary level and $16.17 \%$ reached secondary level against $12.82 \%$ who attended Quranic school. We note that all producers with a primary level of education or even some of the secondary level (especially the $6^{\text {th }}$ and $5^{\text {th }}$ levels of middle school) find it difficult to read a single sentence.

\subsubsection{Profiles of Vegetable Production System}

\section{1) Cultivated speculations}

Irrigated crops have pride of place in Imanan. Several speculations are thus cultivated (Figure 3). The potato dominance effect is fully at work on the sites 
Table 2. Main socio-demographic characteristics of the respondents.

\begin{tabular}{cccc}
\hline \multicolumn{2}{c}{ Socio-demographic characteristics } & Effective $(\mathrm{N}=78)$ & Percentage (\%) \\
\hline & {$[0-16]$ years } & 0 & 0 \\
& {$[16-30]$ years } & 19 & 24.36 \\
& Men & 15 & \\
Distribution by gender and & {$[31-51]$ years } & 4 & 44.87 \\
by age group of respondents & Men & 28 & \\
& Women & 7 & 30.77 \\
& {$[51+]$ years } & 24 & \\
& Men & 14 & 47.43 \\
& Women & 10 & 12.82 \\
Educational level of the & Quranic studies & $10 / 78$ & 29.95 \\
producers surveyed & Primary & $24 / 78$ & 16.17 \\
& Secondary & $13 / 78$ & 0 \\
\hline
\end{tabular}

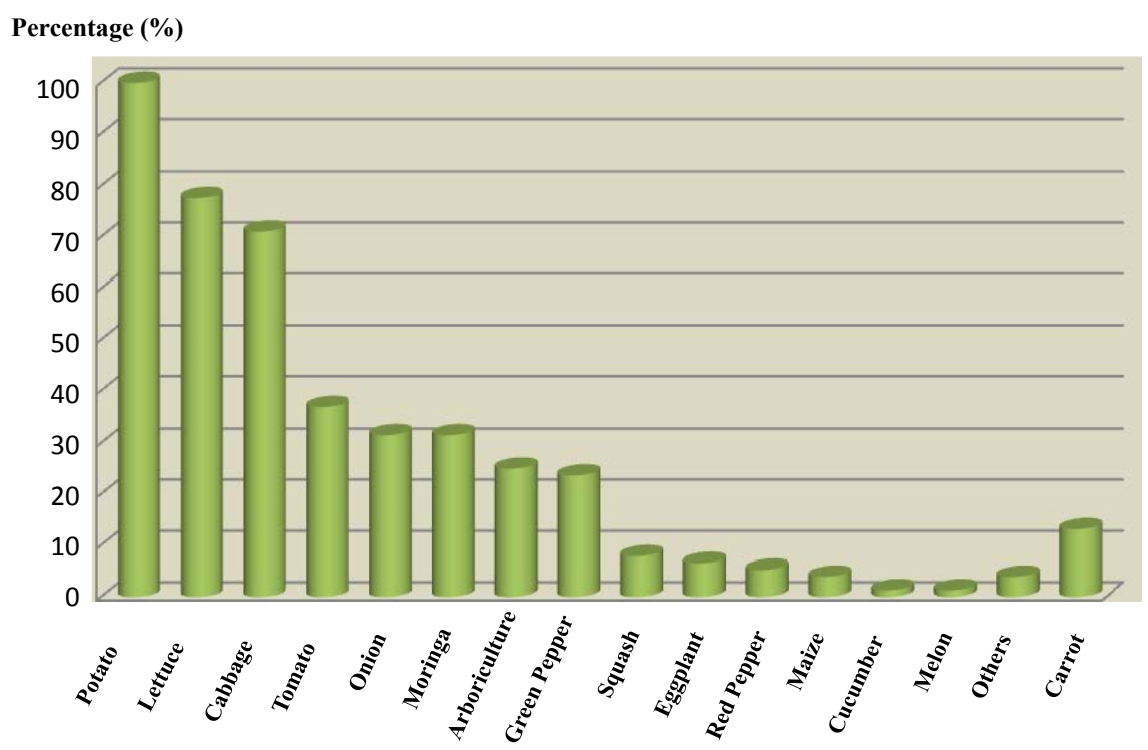

Figure 3. The different crops grown in the commune of Imanan.

(100\% of respondents). Next to the potato (Figure 3), $77.63 \%$ of respondents claim to engage in market gardening of lettuce and cabbage (71.05\%), against tomatoes (36.84\%), onion (31.57\%), Moringa (31.57\%), arboriculture (25\%), pepper $(23.68 \%)$, carrot $(13.15 \%)$, squash $(7.89 \%)$, eggplant $(6.57 \%)$, chilli $(5.26 \%)$ and corn (3.94\%). The other crops consist mainly of okra and sesame (3.94\%), then cucumber $(1.31 \%)$ and melon (1.31\%). It should be noted that some seed crops such as Moringa, peppers and chili peppers are grown during the twelve months of the year.

\section{2) Cropping and irrigation systems}

The cultivation systems, affirmed by the respondents, are of three types, namely: a) Rotation; b) Association SW; c) The pure culture system. Table 3 shows the 
Table 3. Weight of cropping systems practiced in the plots and main types of irrigation processes.

\begin{tabular}{ccc}
\hline Type & & Proportions \\
\hline \multirow{3}{*}{ Cropping systems } & Rotation & $69 \%$ \\
& Pure & $26 \%$ \\
& Association & $5 \%$ \\
\hline \multirow{2}{*}{ Types of irrigation processes } & Pipe & $70.51 \%$ \\
& Watering can & $25.64 \%$ \\
& Irrigation channel & $3.85 \%$ \\
\hline
\end{tabular}

distribution of the proportions allocated to the different types of cropping systems and the main types of irrigation processes. It appears that $69 \%$ of the producers surveyed practice rotation. Then came the pure system with a rate of $26 \%$ against $5 \%$ of producers who practice association. Note that, during the winter season, plots subject to off-season crops are also used for cash crops (cowpeas, peanuts, etc.) and cereals (mainly millet and sorghum). Several forms of irrigation techniques (Table 3) are put into practice by producers. However, $70.51 \%$ of producers use the pipes to irrigate their crops, $25.64 \%$ the watering can and $3.85 \%$ the gutters.

\subsubsection{Agricultural Practices}

\section{1) Techniques for Preparing irrigated plots}

All of the producers surveyed use archaic techniques for preparing the plots (Figure 4). Indeed, the making of the boards by hand is done using instruments such as the daba, the rake, the shovel, the cutter (Figure 4(a)). The start of the preparatory activities of the plots begins for some from mid-September, while for others it is only in October. Thus, initially, the producers clear the plot using the equipment mentioned. This activity consists of cutting all the plants that are in the perimeter to be exploited. The plot is then made clean by systematic sweeping. From then on, the producers water the entire land to make it loose, and thus facilitate the making of the boards. Each year, the plots benefit from a mixture of fertilizers and fencing.

The survey shows that producers use several types of fencing to protect the plots against penetration by animals. Thus, $70.65 \%$ of respondents say they use dead hedges, against $25.35 \%$ for fencing and only $4 \%$ who opt for live hedges system (Figures 4(b)-(d)). Among the users of the wire mesh, 95\% attest to reinforcing it most often by thorny or other species by default (Figure 4(b)). The most widely used species for dead hedges remain Combretum micranthum (Figure 4(c)). Live hedges are made with Acacia Senegal (Figure 4(d)). In general, the species most requested by producers to make their fences are: Combretum micrantum, Guiera senegalensis, Balanites aegyptiaca, Ziziphus mauritiana, Faidherbia albida, Prosopis juliflora.

The producers surveyed affirm that the installation of the ditches requires a lot of technical and therefore financial means. In addition, the women use plastic 


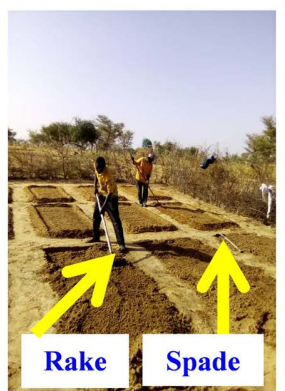

(a)

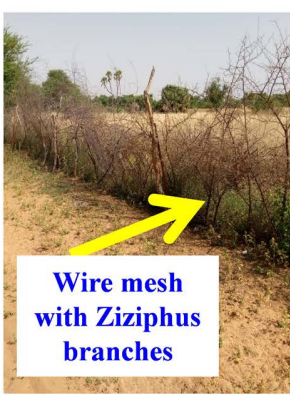

(b)

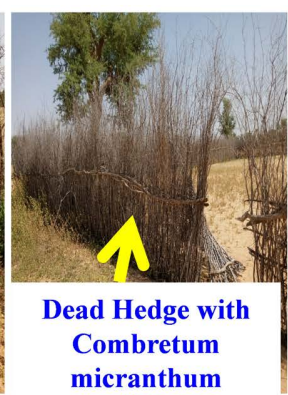

(c)

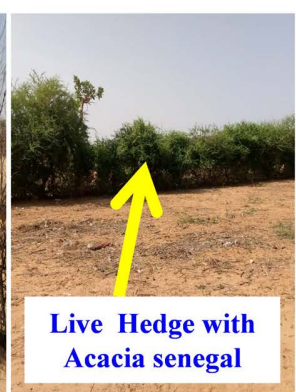

(d)

Figure 4. (a) Making boards with rake, spade and daba [8], and common types of fencing used on sites; (b) Wire mesh completed with ziziphus and/or balanites, Guiera senegalensis; (c) A dead hedge with branches of Combretum micranthum; (d) Live hedge with Acacia senegal.

buckets or basins to store water to gradually use it with the watering cans. For most of the respondents, the use of pipes is the best and most cost effectives way in terms of energy and economically (Figure 5). As a last resort to circumvent evaporation problems, irrigation takes place very early in the morning (some around 5a.m.), in the evening around 5p.m. or even during the nights. However, it appears that through this irrigation system an enormous amount of water is used by the productions. Depending on the dewatering resources, operators have wells (Figure 5(c)), motor pumps (Figure 5(b)) and boreholes which they exploit intensively. For respondents aged fifty and over, opinions are unanimous (100\%): the level of the water table has greatly decreased.

\section{2) Fertilizers in vogue in sites}

In the rural commune of Imanan, the producers surveyed exclusively use three types of fertilizer, including NPK (commonly called 15-15-15), Urea and DAP (Table 4). NPK are generic fertilizers with $3 \%$ of the chemical elements nitrogen $(\mathrm{N})$, phosphate $(\mathrm{P})$, potassium $(\mathrm{K})$. The DAP, a phosphate fertilizer product offered by Hindalco, is part of the fertilizers enriched in Di-ammonium (DAP). It is the most popular phosphate fertilizer.

Table 4 shows that out of 100 producers, $92.95 \%$ use NPK, while $84.50 \%$ of 100 respondents use Urea. Finally, out of 100 producers from the surveyed sites, $49.29 \%$ use the DAP. The survey shows that most producers mix these different types of fertilizer. In addition, on an average area of 0.41 ha, growers apply about $111.50 \mathrm{~kg}$ of fertilizer. Finally, all the respondents are unanimous in affirming that the use of fertilizers is to increase the yield (i.e. in terms of weight or size of the products) and not to restore soil fertility. The frequency of fertilizer application is of two types depending on the growers. The wealthiest producers make a contribution in three phases, the greatest quantity of which during the preparatory phase, then a month after (during tubing) and at the end before harvesting. CAIMA is the main source of fertilizer supplies for producers in the rural commune of Imanan. However, some producers (especially women) buy their products on local markets, in particular those of Bonkoukou, and Balleyara. 
Table 4. Proportions of users depending on the type of fertilizer and according to the type of phytosanitary products.

\begin{tabular}{ccc}
\hline & Type & Proportions \\
\hline \multirow{2}{*}{ Fertilizer } & NPK & $92.95 \%$ \\
& Urea & $84.50 \%$ \\
& DAP & $49.29 \%$ \\
\hline \multirow{2}{*}{ Phytosanitary products } & Piya Piya [DDT] & $32 \%$ \\
& Gamari & $32 \%$ \\
& Titan EC & $13 \%$ \\
& Biopesticides & $3 \%$ \\
& Karate & $3 \%$ \\
& Conquest & $1 \%$ \\
& None & $16 \%$
\end{tabular}

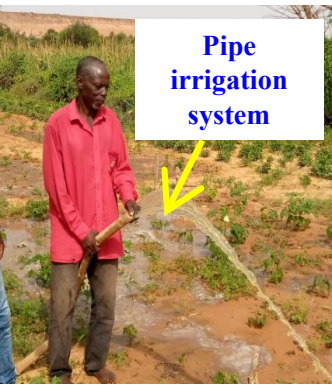

(a)

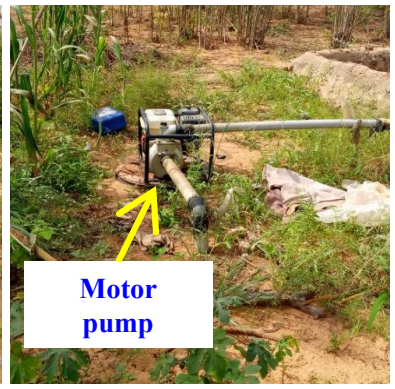

(b)

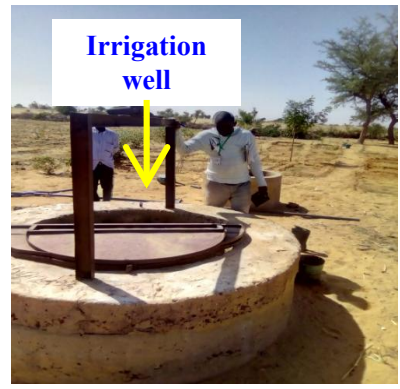

(c)

Figure 5. Irrigation by pipe (a), dewatering motor pump (b) and market gardening well (c) $[8]$.

All the producers surveyed use organic manure but in very variable quantities. The frequency for its use also depends on the users. The majority supply the soil with manure exclusively during the preparatory phase. A partial contribution is made little by little over time for some. This fertilizer is essentially composed of the remains of droppings and dung from sheep, goats, cows and camels. Composting is done by only one producer among those surveyed. He does this using millet stems and leaves, which he prepares and buries in the ground for about 48 hours. He has received training for this purpose.

Similarly, the survey shows that producers in the commune of Imanan use several types of plant protection products. Table 4 indicates that $13 \%$ of producers use an approved product (i.e. Titan EC) for market gardening, against $32 \%$ who apply Gamari, 32\% Piya Piya and 3\% Karate. These last three products are all unregistered and are sold informally on the Bonkoukou and Balleyara markets. These products, of questionable quality, usually come from Nigeria and are often at their expiration date. It can be noted that Piya Piya is the generic of Dichlorodiphenyltrichloroethane (DDT), a powerful insecticide of formula $\mathrm{C}_{14} \mathrm{H}_{9} \mathrm{Cl}_{5}$ which has become a persistent organic pollutant (POP) and is banned in many countries. Biopesticides (e.g. based on neem) are used by $3 \%$ of market gardeners surveyed (Table 4). The latter claim to have received training in the 
manufacture of such products from certain projects and with the assistance of the agricultural services.

Finally, $16 \%$ of producers do not use any phytosanitary product. It should be noted that the respondents who produce only potatoes do not use phytosanitary products. In addition, the dose for phytosanitary products varies not only according to the producers but also according to the type of product. For the entire campaign, an average of 2.5 liters of pesticides are used at a frequency of one week apart. It appears that these products are generally used during an attack observed on seeds. According to respondents, a number of parameters are taken into account before applying pesticides, including wind direction, time of use and type of aggressors.

\subsection{Impacts of Agricultural Practices}

\subsubsection{Main Elements of a Positive Contribution to Environment}

Figure 6 represents the citation rates based on a total of $100 \%$ of respondents and specifically to a socio-economic impact of vegetable production in the commune of Imanan. 100\% of producers say that market gardening allows them to meet their food needs to compensate for the production deficit that harvesting rainfed crops generates. $89.74 \%$ of respondents say that market gardening allows them to buy cattle that they raise and sell in the event of ceremonies and in case of any urgent need.

To this is added the purchasing power of inputs, small working equipment and for the support of workers. In addition, this practice allows producers to meet secondary needs such as children's education, family clothing, health, purchase of animal feed and debt repayment (92.3\%).

Finally, according to the respondents, these activities have greatly contributed to social cohesion between producers and their families. Indeed, during the harvest,

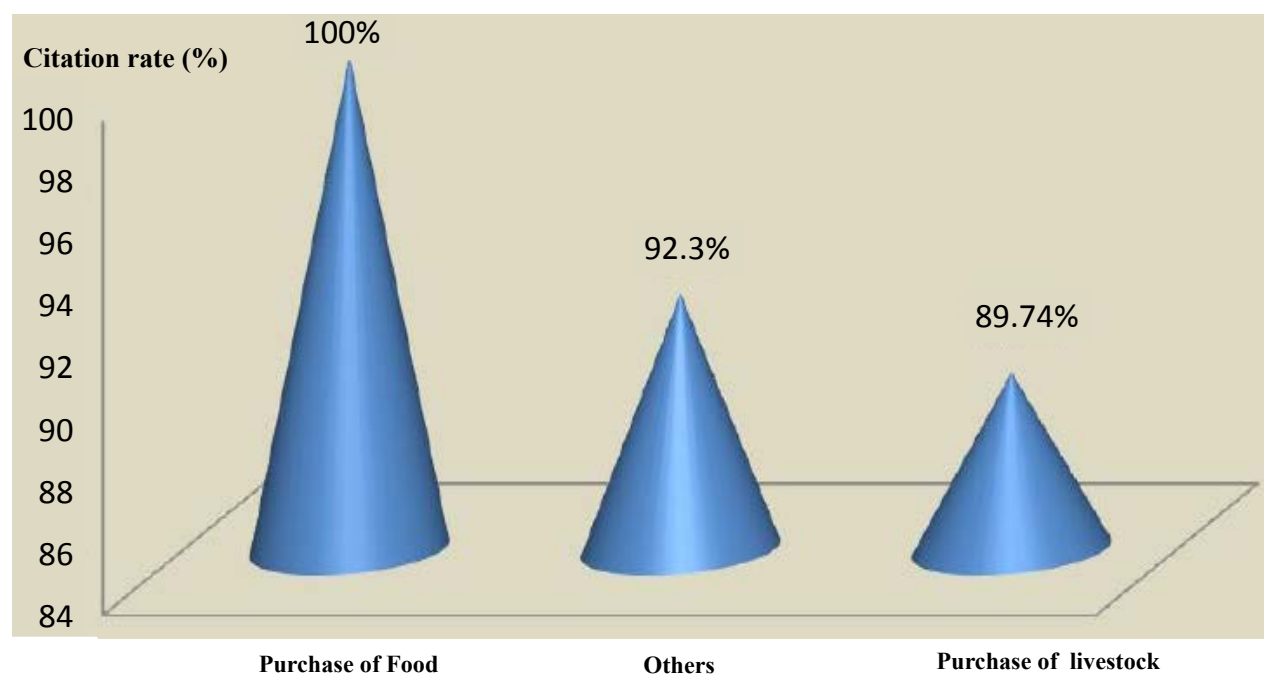

Figure 6. Socio-economic impact of market gardening among respondents. Note that the citation rate, expressed in percentage (\%), is a proportion of respondents out of the total $(100 \%)$ of respondents for each socioeconomic impact. 
part of the production is reserved for relatives, friends and acquaintances or even sympathizers.

The general opinion and as confirmed by Figure 7, as the preparation of the plots approaches, piles of fresh branches of Combretum micranthum are deposited at the level of the plots to be fenced (Figure 7(a)). After the drying that follows, many farmers believe that the falling leaves provide soil fertilization. The ground truth campaign showed that local people are aware that burning debris from old fences (Figures $7(b)$ ) is a source of access to the best soil fertilizer. In addition, the heat shock with the basal surface allows a capillary rise of the water. Futhermore, after the off-season cropping campaign, the majority of the population of Imanan cultivates cowpea during the rainy season on the same plots. It has been observed that this agricultural practice is likely to ensure soil fertilization through the nitrogen fixing power that cowpea possesses. This ensures that some producers do not use too much inorganic fertilizer and supplement with a lot of organic manure from small and large ruminants.

\subsubsection{Dimension of Negative Impacts Linked to Vegetable Production \\ 1) Impacts on the health of producers}

The use of phytosanitary products is the basis of several pathologies (Table 5) including diseases related to respiratory disorders (62.50\% of people surveyed) and skin lesions (10.41\%), then $27.09 \%$ do not declare any health impropriety. It should be noted that women are the least affected by the effects of pesticides.

2) Impacts on water resources, soils and plant cover

In general, $75.46 \%$ of respondents think that the level of the water table has decreased. According to the interviewees, hardly any wells were less than 2 to 4 $\mathrm{m}$ deep. Today, those same wells are at least 7 to $14 \mathrm{~m}$ deep. As one farmer put it

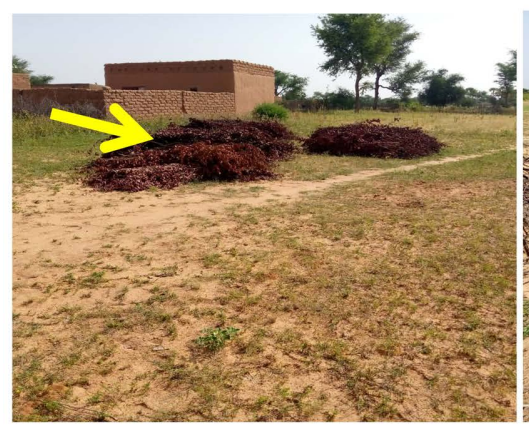

(a)

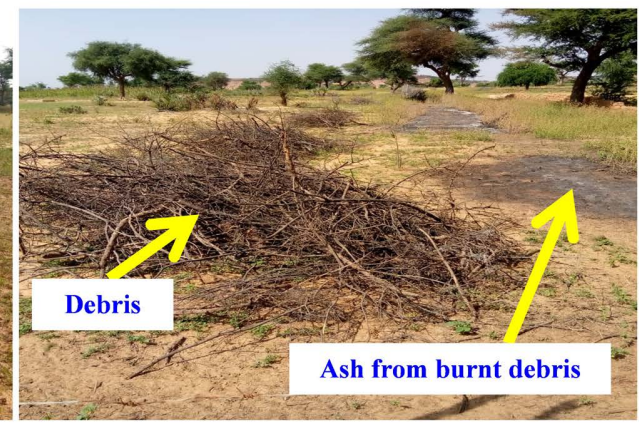

(b)

Figure 7. (a) Branches of Combretum micranthum put to dry on a plot before making the fence and (b) debris from branches of the old hedge intended for burning.

Table 5. Citation rate of pathologies due to the spreading of inputs.

\begin{tabular}{ccc}
\hline Most activities & Pathologies & Percentage \\
\hline & Respiratory problems & $62.50 \%$ \\
Spreading of inputs & Skin lesion & $10.41 \%$ \\
& No pathology & $27.09 \%$ \\
\hline
\end{tabular}


so well: "When I was little, we took our animals to pasture and when we were thirsty, we only needed to dig with our hands to have water to drink." Watering, especially after spreading fertilizer, could promote percolation, leading to a risk of groundwater contamination.

The field survey shows that $98.72 \%$ of the producers surveyed ensure the maintenance of motor pumps on the operating sites, against $1.28 \%$ who had it done in town at the garage. As a result, during the oil change a significant amount of oil spills onto the ground, thus changing the texture of the latter. Figure 8(a) shows a conservation pit for potato production and clearly indicates the dangerousness of the onset of physical soil degradation, in addition to constituting a "reservoir" and "corridor" for the transit of pollutants.

According to the producers (100\% of respondents), the vegetation has disappeared and market gardening is at the heart of this state of affairs. In the area that should be used for crop production (especially for growing potatoes), all trees are cleared. On average, according to the people surveyed, to close a plot of 0.5 ha, takes around 40 timber trips using a donkey cart (Figure 8(b)). Approximately, a donkey trip corresponds to one cubic meter $\left(1 \mathrm{~m}^{3}\right)$. So, to ensure the fence of half a hectare you need at least $40 \mathrm{~m}^{3}$ of wood.

\subsection{Alternatives, Optimization and Corrective Actions in the Field}

Figure 9 presents the failings and wishes of producers to mitigate the negative impacts (or even optimize the most positive) on environmental resources. Thus, $79.49 \%$ of respondents say they need training in cultivation techniques (e.g. cropping system). According to them, it is fitting that only those in charge of the organizations of market gardeners, relatives, friends and acquaintances benefit from the training. In addition, $51.28 \%$ of respondents request external assistance (e.g. subsidies for wire mesh). Finally, $15.38 \%$ of respondents expressed their need for PPE (e.g. gloves) in order to ensure adequate protection against the effects of inputs during their application on the sites.

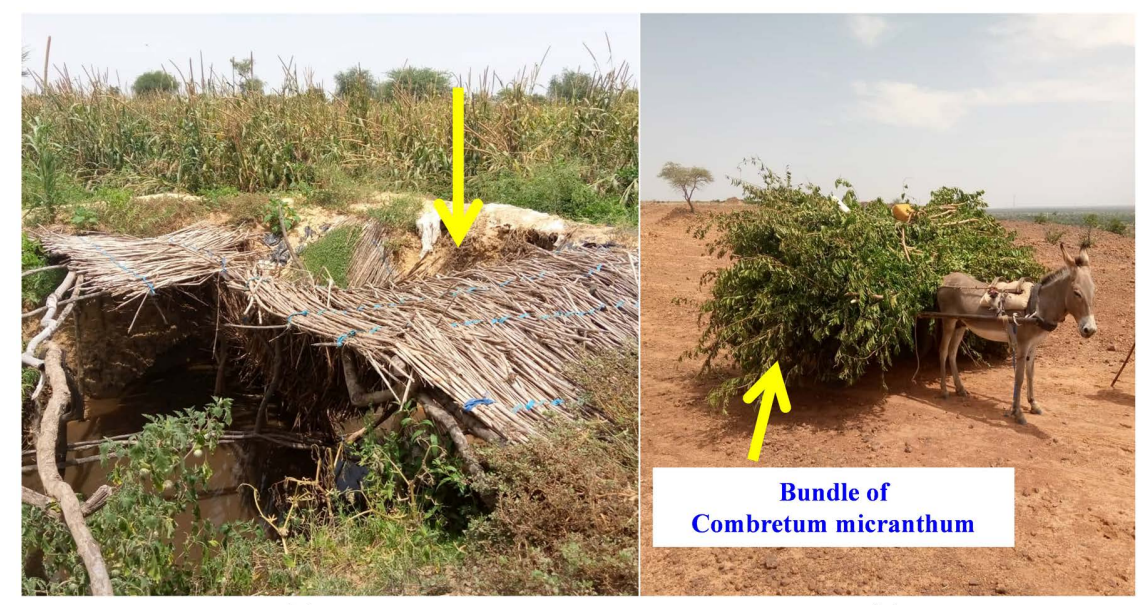

(a)

(b)

Figure 8. (a) Potato storage pit (PSP): a receptacle for runoff water; (b) view of the plateau: a cart loaded with Combretum micranthum. 


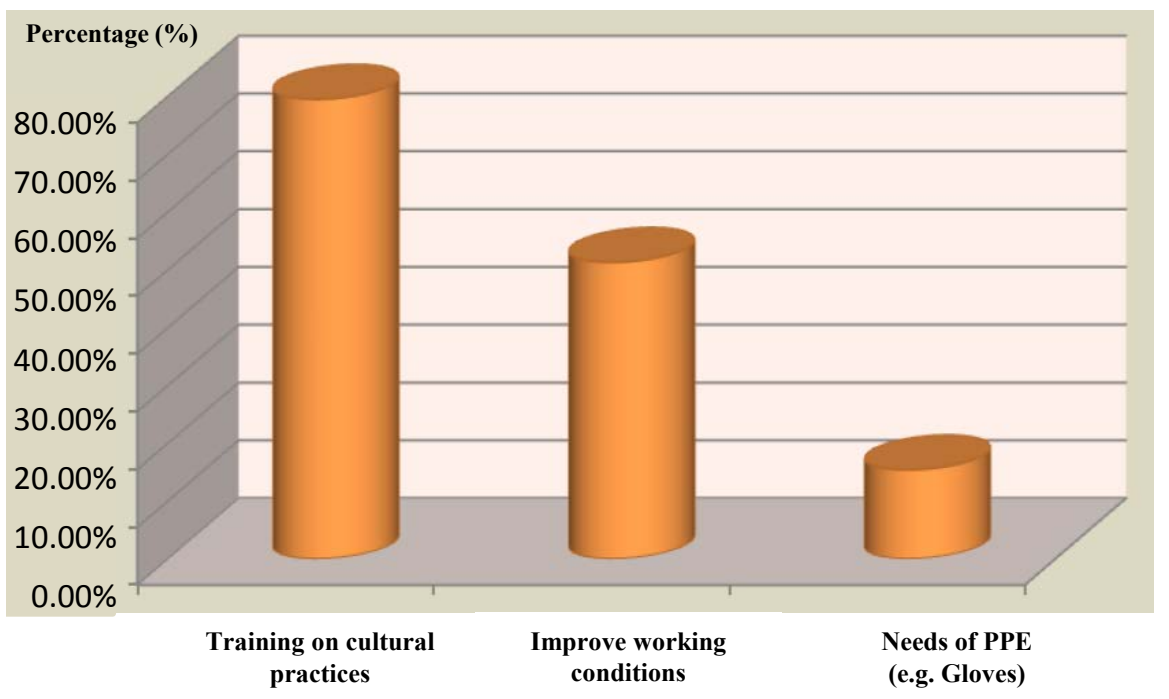

Figure 9. Percentage of citations of negative impact mitigation measures.

\section{Discussion}

In the north-west of Middle Niger, the rural commune of Imanan is distinguished by the abundance of several ponds (permanent, semi-permanent and temporary) and a shallower water table [10]. This particularity is justified by its geographical position: the large valley of Dallol Bosso [15]. The availability of this essential resource has led to the proliferation of vegetable crops in this locality. At the crossroads of a demographic boom and various inputs, proximity to water is attracting more and more new farmers of all kinds and categories. Ultimately, the introduction of motor pump irrigation has made it possible to extend the cultivable areas [8].

\subsection{Market Gardening Practices and Dynamics of Environmental Resources in Imanan}

This study clearly shows that market gardening is more practiced by people between 31 and 50 years old (44.87\% of respondents). Indeed, this fringe of the population represents more able-bodied workers and has more cultivable land. These results are slightly different from those of Muliele et al. [16] who report that producers in the gardening zone of Nkolo (Central Province of Kongo, Democratic Republic of Congo) aged between 20 and over 50 represent the greatest number. However, for more than half of the producers questioned (59.90\%) are without formal education and therefore illiterate and with small proportions for the primary and secondary level. Consequently, compliance with certain standards of cultural practice (e.g. compliance with the dosage for the use of pesticides) remains very difficult. What is remarkable about the visited sites, several speculations are cultivated, including the potato which occupies the first place (100\% of respondents). The results of Kagambega [17] are moderately inferior to these data. Indeed, according to the results of this author, $60 \%$ of producers cultivate potatoes on the Ouahigouya site (Burkina Faso). The difference 
can be explained by the sources of irrigation water supply. The main source of water supply at the Ouahigouya site is the well, while in the rural commune of Imanan, wells remain little used for boreholes and motor pumps.

Additionally, other so-called companion crops are grown (e.g. Moringa). These results are contrary to those of Seydou Oudou [18] obtained in Djiratawa (Maradi, Niger) where Moringa is cultivated by all respondents (100\% of respondents). Rotation is the main cropping system for the producers surveyed with $69 \%$ sample against $26 \%$ for the pure cropping system. Most market gardeners do not have enough land to make the system of pure cultivation, or do not have enough means to develop it. The working tools available to the producers surveyed remain traditional and rudimentary. In fact, dabas, cutters, watering cans and shovels are part of the equipment that makes tillage very difficult and expends more energy. This could be a brake on the emergence of irrigation in the study area. These results corroborate those found by Mahamadou et al. [19]. Thus, producers lack modern tools to increase agricultural output. This reality on the ground would keep these producers in a state that allows them just to cover their daily needs (e.g. purchase of food).

However, if we refer to the statements of the same producers, market gardening and their agricultural choices allow them to meet many basic needs and accumulate wealth. From this point of view, these results corroborate the findings of Hassane [8] and Boubacar Oumarou [9]. Beyond the pecuniary benefits that these activities provide to operators, approximately $73 \%$ of respondents claim to be affected by pathologies (e.g. respiratory disorders and dermatological problems). Indeed, in order to garner more yields, farmers are using and abusing more and more phytosanitary products, especially unapproved ones. The investigation leads to the conclusion that the practice of market gardening in the municipality takes a certain toll on environmental resources.

When preparing the plots, a titanic amount of water is used by all producers to facilitate tillage. This would result in lowering the piezometric level of the aquifer. It is noticed that the tools used by the interviewees are archaic and contribute to an indescribable waste of water during the activities. The authors of [20] observed these facts in Algeria. This is explained by the fact that the potato is too water demanding a species especially during growth and tuberization. Considering the importance of the water resource and the capricious climatic conditions which characterize the study area (Sahel), the use of modern tools (e.g. the drip device) is necessary.

The increasing use of chemical pesticides by market gardeners has emerged as the most effective and cheapest way to control pests and increase production in a small area [21]. This anarchic use of pesticides and abuse of inorganic fertilizers thus exposing the water resource to the risk of groundwater pollution. These results join those of Mahamadou et al. [19] in the Kantché zone (Zinder region, Niger). Chemical analysis is needed to confirm the hypothesis. Also, as one producer pointed out, this misuse of inputs degrades soil fertility so that agricultural land becomes increasingly infertile (e.g. the problem of salinization; 
[13]). Unlike the irrigated perimeter of Djiratawa [18], where association is the main method of cultivation, rotation constitutes the main cultivation system in Imanan. Such a system contributes to soil degradation on the sites. Currently, there is overexploitation (i.e. no fallow) of land. This has contributed to the aging of the resource by causing its degradation. In addition, the extension of cultivable areas, like the demographic growth that characterizes Niger, has greatly favored the phenomenon of runoff and therefore erosion [22]. The increase in the phenomenon of arable land has indeed contributed to massive destruction of vegetation. As Souley Yero [23] has already pointed out, in his study area, deforestation is also marked by the clearing and cultivation of forests. These facts can be explained by the fact that our study areas belong to the same part of Niger (West) where the populations have the same concern which is the increase in crop fields to face the galloping demography which undermines the country. Studies conducted by Camard and Magdelaine [24] have shown that the uncontrolled use of inputs contributes to the destruction of biodiversity in general and, in particular, vegetation. The authors of [24] define pesticides as substances that make it possible to prevent, control or eliminate organisms considered undesirable, whether they are plants, animals, etc. From this and with the uncontrolled use of these pesticides, we deduce that the vegetation is destroyed.

For $70.65 \%$ of those questioned, the protection of irrigated plots still depends on dead hedges. The renewed use has greatly contributed to the disappearance of the vegetation cover (Figure 10). As pointed out by Hassane Seyni et al. [25], the branches of thorn trees constitute for the majority of producers the means to protect their plots. The agreement of our results can be explained by the meager financial means available to most of the people surveyed. Either way, clearing, done by new producers or for suppliers of wood to renew fences, exposes the soil to the phenomena of water and wind erosion (Figure 10(a)). The consequences are, on the one hand, the generalized development of crusting beaches on the slopes and therefore favorable to runoff (Figure 10(b)), then the multiplication of large lateral gullies with torrential flows during exceptional rainfall events [26]. As for the bare soil and sheltering many potato storage pits, it remains at the mercy of erosive agents (water and wind) which move pollutants as they please (waste oils, inputs and pesticides), ravel the current landscape with of course the contribution of the practices of market gardeners. This change in surface conditions is at the origin of the development at an accelerated rate of a dynamic of quantitative and qualitative degradation of species within the plant cover of plateaus and slopes (Figure 11). As so well underlined in the Middle Niger [23], we are today inevitably witnessing the effective disappearance of plant cover. In the study area, some producers were trained in Assisted Natural Regeneration (ANR). According to Larwanou and Abasse [27], the ANR is based on existing strains where natural suckers which are selected, pruned and protected to accelerate growth contrary to the conventional practice of the peasants, which was to systematically cut off the shoots when preparing the fields. The mayor of Imanan confirmed that the Community Action Program III project 


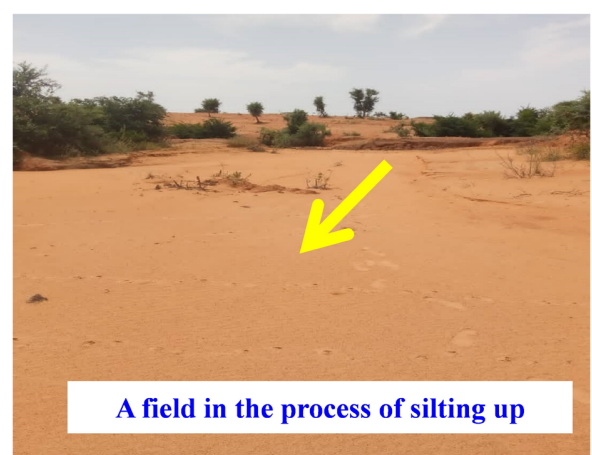

(a)

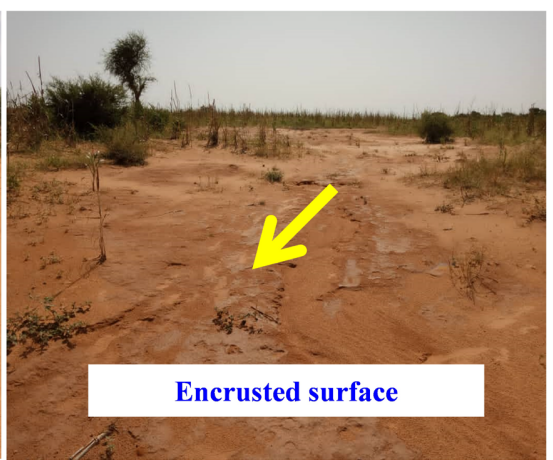

(b)

Figure 10. (a) View of the plateau exposed to the phenomena of deforestation and desertification. (b) Encrusted surface undergoing the double phenomenon of water erosion and wind deflation.

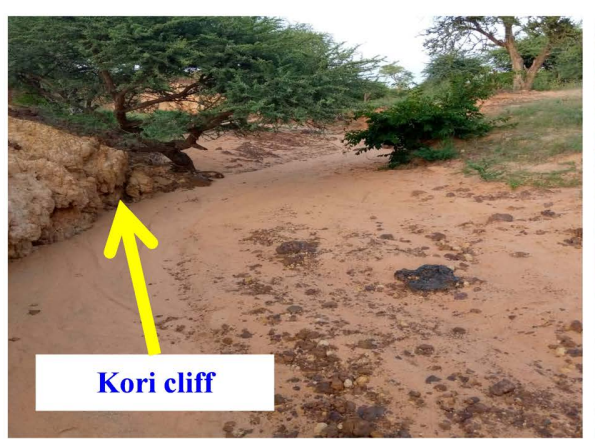

(a)

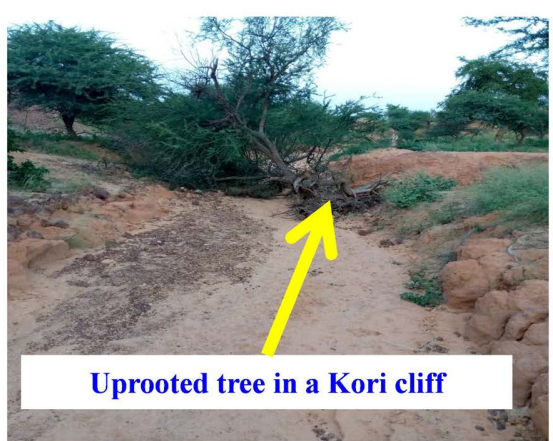

(b)

Figure 11. Consequences on the slopes of the influence of the new morphodynamics in the current landscape.

(PAC3) [10] initiated 11 pilot villages for the practice of ANR. Although practiced on a small scale, some producers use this technique to ensure the re-greening of vegetation and the protection of plant species. Recourse to rain-fed cowpea cultivation on the same plots is likely to ensure soil fertilization through the nitrogen fixing power that cowpea possesses [28].

Similarly, the drying of the branches intended for the fences, which results in, among other things, an amendment of the foliage left in the plots, has considerably impacted the practice of soil fertilization by the farmers. Since some growers deduce the uselessness of inorganic fertilizers so that they supplement humic amendments with a lot of organic manure. Finally, mulching and burning remain part of the framework for improving certain physicochemical properties of the soil.

\subsection{Responsibilities, Policy and Regulatory Initiatives}

In the rural commune of Imanan, compliance with the regulations vis-à-vis the protection of natural resources as being a common heritage is in violation by the producers surveyed. In this sense, we note the non-respect of the framework law $n^{\circ}$ 98-56 of December 29, 1998 relating to the management of the environment, 
in particular in its articles 55 and 78 [9]. Indeed, producers use natural resources (e.g. soil) in a non-rational way that tends to degrade these expensive and irreplaceable resources. These facts are also observed by Assoumane Kelé [28]. Thus, he reports that the producers surveyed use an enormous amount of inputs tending to optimize yield to the detriment of natural resources.

In addition, article 52 of the same law is not in force. Because the very intense use of pesticides degrades water quality. This remark had already been made in the gardening zone of Ngaoundere City of Cameroon [29] and elsewhere [21]. In fact, non-compliance with the Basel Convention has been observed in the study area. Indeed, the marketing of unapproved and dangerous products is done in this locality. Violation of this convention hinders the protection of environmental resources through the use of inputs not recommended for market gardening [9].

The results of our survey stipulate that to mitigate the negative impacts associated with the practice of market gardening, a number of measures must be taken. On the other hand, the application of these measures requires the full involvement of all the actors concerned by the agricultural sector. And this is for the sole purpose of rational exploitation of environmental resources. Ultimately, most of the people surveyed (79.49\%) say they need training in cultivation techniques. These results remain in agreement with the study carried out by Seydou Oudou [18].

\section{Conclusion}

The Bonkoukou valley, capital of the commune of Imanan in the department of Filingué (Tillabéry region) in Niger, is the space for rainfed crops and per excellence for off-season crops. Indeed, the shallow water table and the influence of light sandy to loamy-sandy soils allow certain activities to develop, in particular market gardening. Thus, in addition to rainfed production (millet and sorghum) with little production, when the rains are insufficient and poorly distributed over time, potatoes are widely cultivated there. All the lands (the courtyard of the houses, the streets, the plateaus and the valleys) are exploited. While potato cultivation can be linked to substantial income for producers to enable them to secure their livelihoods, the primary problem for the bewildered state institutions is the magnitude of the impact of these practices on environmental resources. A sample of 78 respondents was carried out on five collective sites (Balley Koira, Iguefane, Eggrou, Kochilan Touareg and Femmes INRAN) of the 17 collective sites listed, two hamlets (Labongou and Inacli) and individual sites in the confines of the city of Bonkoukou. The loss of plant cover is one of the biggest factors in the degradation of environmental resources. To the perpetual renewal of the hedges, is added the clearing of cultivable land, which has contributed to the massive destruction of vegetation already threatened by other uses. It is also noted that this state of affairs promotes soil degradation which will result in water and wind erosion. The practice of market gardening appears, that it comes up 
against two main difficulties. The first is the popularity of this activity, and therefore the increase in the number of producers and cumulatively in that of cleared land. The second is the lack of supervision of producers. In many sites in the commune, the anarchic use of inputs raises serious concerns and debates on human health and the environment. It would have been necessary to measure and give with precision the impacts of the excessive use of fertilizers on the quality of the potato tubers and the degree of pollution of the water table which humans and animals rely on for their water supply.

\section{Acknowledgements}

The authors are grateful to and acknowledge the substantial and precious help of the valiant producers of the Imanan Municipality, the Honorable Chief of the canton of Imanan, the Town Hall of Bonkoukou, the staff of FCMN Niyya and the Environment services, Agriculture and Hydraulique of Bonkoukou and Filingué. Very sincere thanks to the reviewers who agreed to judge and improve the quality of the basic manuscript.

\section{Conflicts of Interest}

The authors declare no conflicts of interest regarding the publication of this paper.

\section{References}

[1] Panissi, A. and Anziani-Vente, M. (2019) Rapport intermédiaire-Projet "Doutchi Climat" au Niger: Renforcer la résilience au changement climatique et lutte contre la désertification en Aréwa (Janvier 2017-Décembre 2019). ECODOTA (Niamey, Niger) et Eau Vive Internationale (France).

[2] Programme des Nations Unies pour le développement (PNUD) and Bureau de la prévention des crises et du relèvement (BCPR) (2013) Gestion durable des zones humides face aux risques climatiques au Niger: Le cas de la mare de Tabalak. PNUD/ BCPR, New York.

[3] PPAAO/WAAP-1C (2016) Programme de Productivité Agricole en Afrique de l'Ouest. Cadre de Gestion Environnementale et Sociale. Rapport du Ministère d'Agriculture, Niamey.

[4] Sultan, B. and Janicot, S. (2004) La variabilité climatique en Afrique de l'Ouest aux échelles saisonnière et intra-saisonnière: Mise en place de la mousson et variabilité intra-saisonnière de la convention. Sécheresse, 15, 1-10.

[5] INS (2016) Institut National de la Statistique. Statistique de l'éducation de base et alphabétisation 2015-2016, Niamey.

[6] Nazoumou, Y., Favreau, G., Adamou, M.M. and Mainassara, I. (2016) La petite irrigation par les eaux souterraines, une solution durable contre la pauvreté et les crises alimentaires au Niger? Cahiers Agricultures, 25, Article ID: 15003.

[7] Bonkoula, A., Barrage, M., Lawali, N.A. and Watara, M.S. (2007) Étude sur la filière pomme de terre et les méthodes de conservation du produit en vue de sa vente en décalé dans le cadre d'opération de warrantage dans le secteur géographique de Bonkoukou, Département de Filingué, Région de Tillabery au Niger. SOS Sahel, Niamey. 
[8] Hassane, R. (2015) La production de la pomme de terre et recomposition socioéconomique dans l'Imanan, Niger. Ph.D. Thesis, Université de Toulouse JeanJaurès, Toulouse.

[9] Boubacar Oumarou, R. Impacts de la pratique du maraîchage sur les ressources environnementales dans la commune rurale d'Imanan (Tillabéry, Niger). Master Thesis, Université de Dosso, Dosso.

[10] Commune Rurale d'Imanan (CRI) (2020) Plan de Développement Communautaire de la commune rurale d'Imanan (Bonkoukou, Filingué, région de Tillabéry, Niger).

[11] Sido Yacouba, A., Yadji, G., Mamane Tchicama, M. and Abdourahamane Issa, N. (2019) Caractérisation des sols de Guillé Koira et Lassourou dans les communes rurales d'Imanan et Tondikandia au Niger pour une meilleure culture de riz autour des mares. International Journal of Biological and Chemical Sciences, 12, 24742485. https://doi.org/10.4314/ijbcs.v12i6.2

[12] Dubois, D., Icole, M. and Trichet, J. (1984) Évolution géomorphologique de la vallée du Niger aux abords de Niamey (République du Niger). Bulletin de la Société Géologique de France, 26, 1305-1318. https://doi.org/10.2113/gssgfbull.S7-XXVI.6.1305

[13] Oumarou, I., Ousseini, I. and Ambouta, J.M.K. (2009) Gestion de l'eau et décentralisation au Niger: Cas de la mare de Tashi (Bonkoukou, Filingué), 1-21.

[14] Ambouta, J.M.K. (2015) Cours de couverture pédologique. Master 2 GISE 238 diapositives, Faculté d'agronomie de l'Université Abdou Moumouni, Niamey.

[15] Maïnassara, I. (2010) Ressources en eau dans la région de Tillabéri (Sud-Ouest Niger) et leur potentiel de mise en valeur par l'agriculture irriguée. Master GIRE, Institut International d'Ingénerie de l'eau et de l'Environnement (2iE), Ouagadougou.

[16] Muliele, T.M., Manzenza, C.M., Ekuke, L.W., Diaka, C.P., Ndikubwayo, D.M., Kapalay, O.M. and Mundele, A.N. (2017) Utilisation et gestion des pesticides en cultures maraîchères: Cas de la zone de Nkolo dans la province du Kongo central, République démocratique de Congo. Journal of Applied Biosciences, 119, 11954 11972. https://doi.org/10.4314/jab.v119i1.11

[17] Kagambega, L. (2015) Impact socio-économique de l'organisation des producteurs sur la production maraîchère au Burkina Faso: cas de Bobo-Dioulasso, Ouagadougou et Ouahigouya. Mémoire Diplôme d’Ingénieur du développement rural. Institut du Développement Rural (IDR) de l'Université polytechnique de Bobo-Dioulasso (UPB), Bobo-Dioulasso.

[18] Seydou Oudou, M. (2020) Perceptions paysannes de l'impact des pratiques agricoles sur les ressources environnementales (sols, eaux, végétation): Cas du périmètre irrigué de Djiratawa (Maradi, Niger). Mémoire de Licence EIE, Université Dan Dicko Dankoulodo, Maradi.

[19] Mahamadou, I., Joachim, B., Kabirou, S. and Sani, O.B. (2018) Analyse des contraintes foncières et culturales du maraichage dans le département de Kantché au Niger: Cas du périmètre irrigué de Tassaou. European Scientific Journal, 14, 240-255. https://doi.org/10.19044/esj.2018.v14n30p240

[20] Lahouel, Z. (2015) Étude diagnostique de la filière pomme de terre dans la région de Tlemcen, cas de deux fermes pilotes: Hamadouche et Belaidouni. Mémoire Master, Université Aboubekr Belkaïd-Tlemcen, Alger.

[21] Houeyissan, S. (2006) Effets de l'utilisation des pesticides sur la santé et l'environnement dans le maraichage sur les sites de Cotonou et environs. Mémoire Diplôme d'Ingénieur Agronome, Université d'Abomey-Calavi, Abomey-Calavi.

[22] Abdourhamane Toure, A., Rajot, J.L., Garba, Z., Guillon, R., Tidjani, A.D., Marticorena, 
B., Petit, C. and Sebag, D. (2013) Six années de suivi du flux d'érosion éolienne sur un sol sableux cultivé au Sahel: impacts des résidus de culture et de l'encroûtement. Étude de Gestion des Sols, 20, 55-68.

[23] Souley Yero, K. (2013) Évolution de l'occupation des sols dans l'Ouest du Niger: Influence sur le cycle de l'eau. Ph.D. Thesis, Université de Grenoble, Grenoble.

[24] Camard, J.P. and Magdelaine, C. (2010) Produits phytosanitaires, risques pour l'environnement et la santé: Connaissances des usages en zone non agricole. Institut d'Aménagement et d'Urbanisme (IAU) de l'île-de-France, Paris.

[25] Hassane Seyni, H., Ousmane, B., Soumana, I. and Yamba, B. (2014) Impacts des activités socio-économiques sur les ressources en eau du Barrage de Téra au Niger. Afrique Science, 10, 149-172.

[26] Moussa, M.S. (2006) SIG et dynamique de l'occupation du sol du bassin versant du kori Goubé dans le degré carré de Niamey. Mémoire DEA, Université Abdou Moumouni, Niamey.

[27] Larwanou, M. and Abasse, T. (2009) Les techniques de regénération naturelle assistée (RNA) au Sahel. Manuel de formation à l'intention des agents de vulgarisation et des producteurs Sahéliens. ICRAF Training Material, Niamey.

[28] Assoumane Kelé, I. (2007) Pratiques culturales de production de la pomme de terre à Bonkoukou. Rapport de stage MSA, Université Abdou Moumouni, Niamey.

[29] Assokeng, T., Siéliéchi, J. and Noumi, G. (2017) Evaluation of Health and Environmental Risks of Pesticide Products Used in Market-Gardening in the City of Ngaoundere (Cameroon). Journal of Agricultural Chemistry and Environment, 6, 186-198. https://doi.org/10.4236/jacen.2017.64013 